\title{
Społeczna funkcja własności w planowaniu przestrzennym
}

\section{Witold Andrzej Werner}

\section{STRESZCZENIE}

Rozwój społeczno-gospodarczy wymaga coraz częściej korygowania interpretacji prawa własności w kierunku ograniczania właściciela w jego wykonywaniu. Własność nie jest bezwzględnym prawem podmiotowym, lecz funkcją społeczną, a granice prawa własności wyznaczają ustawy i zasady współżycia (interesu) społecznego. Prawo własności nieruchomości odgrywa szczególną rolę w odniesieniu do planowania przestrzennego w skali makro oraz w skali pojedynczych inwestycji, stanowi bowiem immanentną część konsekwencji ekonomicznych. Egzekutorami ograniczania prawa własności są organy państwowe i samorządowe, których zadaniem są nie tylko prawnie uzasadnione decyzje wywłaszczenia, lecz również nadzór nad współzależnością wartości strat i rekompensat. Istotną rolę kontrolną w procesie zmian własnościowych pełni tzw. informacja publiczna, umożliwiająca zainteresowanym właścicielom wgląd w zamiary projektowanych przekształceń.

Słowa kluczowe: istota własności, interes społeczny

\section{Deklasacja istoty własności}

W świadomości społecznej, własność, zwłaszcza w odniesieniu do nieruchomości, stanowi tabu pojmowane jako nietykalna świętość. Naruszanie prawa własności było w znaczącej części przypadków przyczyną wojen w skali państw oraz działań i procesów indywidualnych posiadaczy nieruchomości, najczęściej gruntowych, rzadziej budynkowych i lokalowych.

Własność już w starożytności była przedmiotem rozważań filozoficznych. Własność prywatna według Platona stanowi czynnik moralnie i politycznie dezintegrujący społeczeństwo. Arystoteles podkreślał natomiast, że własność daje poczucie ekonomicznej odpowiedzialności. Kościoły chrześcijańskie zdecydowanie opowiadają się za własnością prywatna, natomiast dostrzegają społeczne obowiązki wynikające z tego prawa.

Współcześnie, we wszystkich krajach, prawo własności definiowane i chronione jest przez systemy prawne formułowane w najważniejszych ustawach, konstytucjach i dekretach, mniej lub bardziej wyodrębniających kategorie własności prywatnej i publicznej (grupowej). Z zapisów we wspomnianych systemach prawnych wyraźnie wynika, że prawo własności nie jest prawem absolutnym. 
Konstytucja Rzeczypospolitej Polskiej [Konstytucja RP 1997] w art. 64 w ust. 1 zapewnia, że „każdy ma prawo do własności”, lecz już w ust. 3 wprowadza zastrzeżenie, że „własność może być ograniczona tylko w drodze ustawy i tylko w zakresie, w jakim nie narusza istoty prawa własności". W Kodeksie Cywilnym w art. 140 wprowadzono zapis, że właściciel może „korzystać z rzeczy zgodnie ze społeczno-gospodarczym przeznaczeniem swego prawa", a w granicach tego prawa „wtasność gruntu rozciaga się na przestrzeń nad i pod jego powierzchniq". Stosownie do treści przepisu art. $140 \mathrm{KC}$, granice prawa własności wyznaczają ustawy, zasady współżycia społecznego oraz społeczno-gospodarcze przeznaczenie prawa [Ustawa Kodeks Cywilny 1964].

W ustawie o planowaniu i zagospodarowaniu przestrzennym [Ustawa o planowaniu $i$ zagospodarowaniu przestrzennym 2003] wskazano, że w planowaniu przestrzennym uwzględnia się zarówno prawo własności, jak też potrzeby interesu publicznego, przez który należy rozumieć „uogólniony cel dążeń $i$ działań, uwzględniających zobiektywizowane potrzeby ogółu społeczeństwa lub lokalnych społeczności, zwiazanych z zagospodarowaniem przestrzennym".

Wywłaszczanie nieruchomości, polegające na pozbawieniu lub ograniczeniu prawa własności oraz wysokości odszkodowania za wywłaszczenie, określa ustawa o gospodarce nieruchomościami [Ustawa o gospodarce nieruchomościami 1997], odsyłając do przepisów trybu wywłaszczenia „z urzędu” (rozdziały 4. i 5. ustawy), w pewnym sensie abstrahuje od później uchwalanych tzw. „specustaw” dotyczących głównie inwestycji komunikacyjnych i infrastrukturalnych.

Najbardziej spektakularnym wyrazem ograniczania, bądź pozbawienia prawa własności, są decyzje podejmowane na najwyższych szczeblach władzy, dotyczące budowy lub gruntownej przebudowy dużych zespołów miejskich lub znaczących obiektów infrastrukturalnych, takich jak lotniska, zapory wodne, porty, elektrownie, oczyszczalnie ścieków itd.

Można tu wymienić decyzje budowy całkowicie nowej stolicy w Brasilii, Astany w Kazachstanie czy Agadiru, po niszczącym trzęsieniu ziemi w Maroku, jak też generalne przebudowy i tworzenie wielkich osi komunikacyjnych bądź widokowych w Paryżu, Barcelonie, a po II wojnie światowej również w Warszawie, na podstawie generalnego upaństwowienia gruntów dekretem Bieruta.

Bez względu na kontekst polityczny, wszystkie przykładowo wymienione decyzje $\mathrm{w}$ imię społecznego (publicznego) interesu poprawy zagospodarowania przestrzennego i/oraz poprawy wizji miasta, pozbawiły właścicieli nieruchomości prawa decydowania o wykorzystaniu własnej nieruchomości, przy czym problem rekompensaty za utracone prawo własności stał się drugorzędny w stosunku do „dobra ogólnego".

„Jest zatem rzecza oczywista, że wtasność zobowiazuje, co sprawia, że prawa właściciela moga ulegać różnym ograniczeniom, zwłaszcza gdy wymagaja tego zasady solidaryzmu społecznego. Własność nie jest więc bezwzględnym prawem podmiotowym, lecz funkcja społeczną" [Gurgul 2017, s. 17]. 
„Wywtaszczenie jest wyjątkowa, szczególna forma ingerencji w sferę własności, dopuszczalna w wypadkach, gdy w gre wchodzi cel publiczny. Łaczy się ono z ograniczeniem lub odjęciem $w$ całości prawa własności $w$ drodze aktu indywidualnego, dotyczacego konkretnego podmiotu. Polega ono na nabyciu przez państwo własności nieruchomości lub innego prawa do nieruchomości, będacej własnościa podmiotu niepaństwowego, w drodze ściśle sformalizowanego postępowania administracyjnego, połaczonego z jednoczesnym wypłaceniem wywłaszczonemu odszkodowania określonego przez przepisy wywłaszczeniowe" [Trybunał Konstytucyjny 2008, wyrok K 61/07].

Bardziej złożonym problemem, nieznajdującym dotychczas interpretacji w doktrynie, jest ograniczanie części prawa własności za zgodą właściciela, lecz w połączeniu z niezbędnym postępowaniem administracyjnym. Dotyczy to sytuacji inwestycyjnych, w których uzasadnione jest naruszenie warunków, jakim powinny odpowiadać budynki i ich usytuowanie [Rozporzadzenie Ministra... 2002] za zgodą właściciela, połączoną z właściwym odszkodowaniem, lecz wymagającą zgody administracyjnej.

\section{Interes społeczny jako podstawa naruszenia prawa własności}

Interes społeczny, podobnie jak interes publiczny, zakwalifikować można do tzw. klauzul generalnych, celowo niedookreślonych, odsyłających do kryteriów również pozaprawnych. Podstawowe problemy związane z możliwościami naruszenia prawa własności w imię interesu publicznego (społecznego) określone zostały we wspomnianych już ustawach bezpośrednio związanych z gospodarowaniem przestrzenią, ustawach o ochronie środowiska, drogach publicznych, robotach górniczych oraz innych, zwłaszcza tzw. „specustawach” drogowych, kolejowych, lotniskowych, powodziowych, które obejmują m.in. możliwości naruszenia - ograniczenia prawa własności z tytułu hałasu, zanieczyszczenia powietrza, promieniowania, bezpieczeństwa związanego z liniami przesyłu (rurociągami), szkodami górniczymi i komunikacyjnymi.

Można zatem stwierdzić, że interes publiczny stanowi podstawę do władczej ingerencji administracji publicznej w sprawy jednostek. Według orzeczenia Sądu Najwyższego z 2002 r. [Sąd Najwyższy 2002] interes ogólny zawiera w sobie również słuszne interesy jednostek.

Naruszenie prawa własności występuje także w wyniku uchwalania miejscowych planów zagospodarowania przestrzennego określonych obszarów, które stają się „prawami miejscowymi", obowiązującymi na określonym obszarze, mimo braku odniesienia do wyodrębnionej, indywidualnej rangi ustawowej.

Przykładem może być miejscowy plan przedstawiony na rycinie 1., którego uchwalenie w słusznym interesie publiczno-społecznym spowodowało naruszenie praw własności właścicieli poszczególnych nieruchomości objętych granicami opracowania, a przede wszystkim „naruszenie” (skorygowanie) wartości tych nieruchomości. 


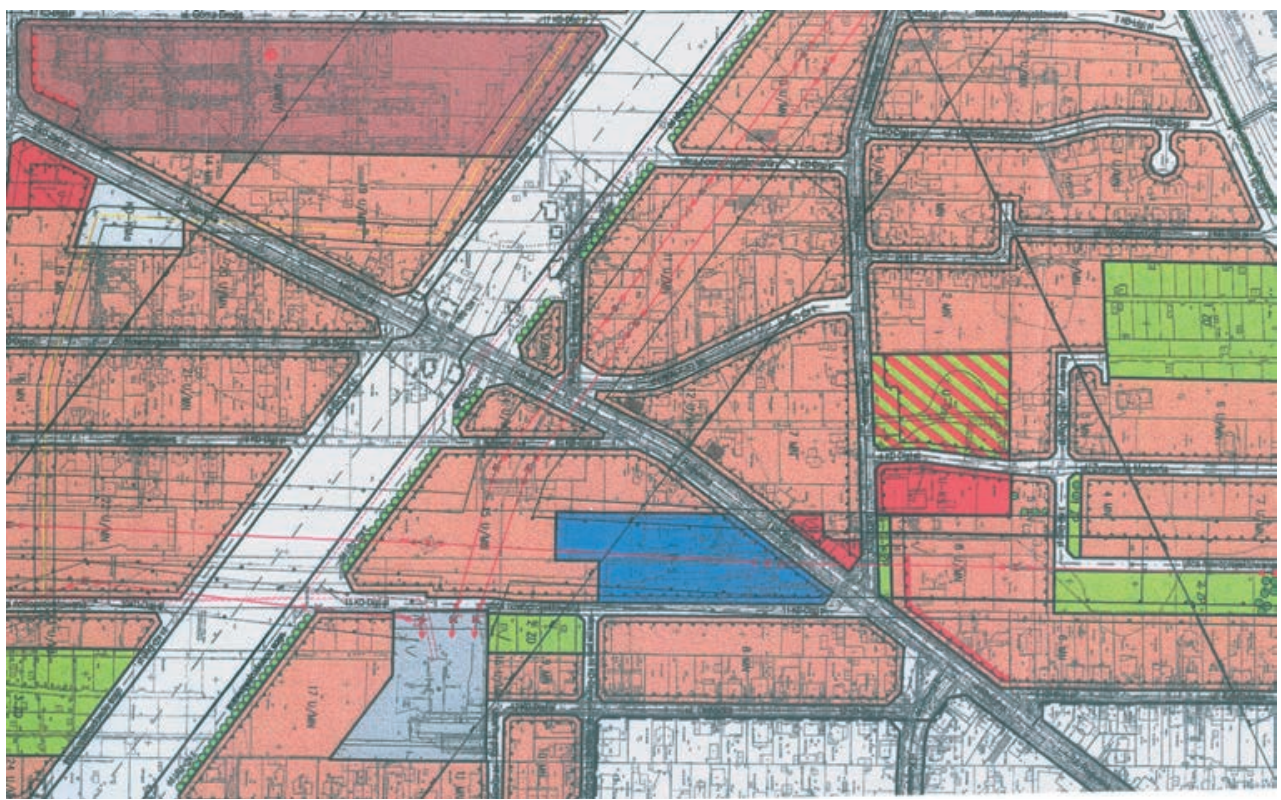

Ryc. 1. Projekt miejscowego planu zagospodarowania przestrzennego

Źródło: opracowanie własne

Przeprowadzenie przez analizowany teren drogi krajowej pozbawia, co jest rzeczą oczywista, własności gruntów zajętych pod drogę, ale również powoduje obniżenie wartości nieruchomości w pasach wzdłuż drogi wskutek zwiększonego hałasu komunikacyjnego.

1. Wyznaczenie pasa ochronnego od hałasu kolejowego od północy oraz lotniskowego od zachodu zdefiniowało obniżoną wartość tych nieruchomości i ograniczoną przydatność.

2. Uporządkowanie dróg wewnątrz obszaru, planistyczne ich utwardzenie i wyposażenie $\mathrm{w}$ pełną infrastrukturę techniczna, poza w/w skutkami, powoduje wzrost cen nieruchomości.

3. Uściślenie przeznaczenia poszczególnych terenów i dopuszczalnej wysokości oraz gęstości zabudowy ułatwia ich zagospodarowanie i powoduje wzrost cen jednostkowych.

4. W okresie do 5 lat po uchwaleniu planu, sprzedaż nieruchomości obciążona jest opłatą w określonej proporcji do wartości nieruchomości, co praktycznie ogranicza transakcje.

Inny przykład wpływu uchwalenia miejscowego planu zagospodarowania przestrzennego na ograniczone wykorzystanie prawa własności przedstawiono na rycinie 2 . Wąski, wydłużony pas terenu objęty planem miejscowym nie pozwala na wykorzystanie dopuszczalnej wysokości zabudowy budynkami 14 kondygnacyjnymi ze względu na ograniczenia wynikające z przepisów dotyczących wymaganego nasłonecznienia mieszkań. Gabaryty przedstawionych budynków i ich wzajemne usytuowanie były przedmiotem licznych symulacji architektonicznych, zmierzających do potencjalnie najlepszego wykorzystania walorów ekonomicznych przestrzeni. 
O wpływie na wykorzystanie prawa własności i potencjalnych korzyści z zainwestowania tego terenu w zasadniczym stopniu decyduje niesprecyzowane prawnie pojęcie „zabudowa śródmiejska uzupełniająca”, która pozwala na ograniczenie wymagań nasłonecznienia mieszkań.

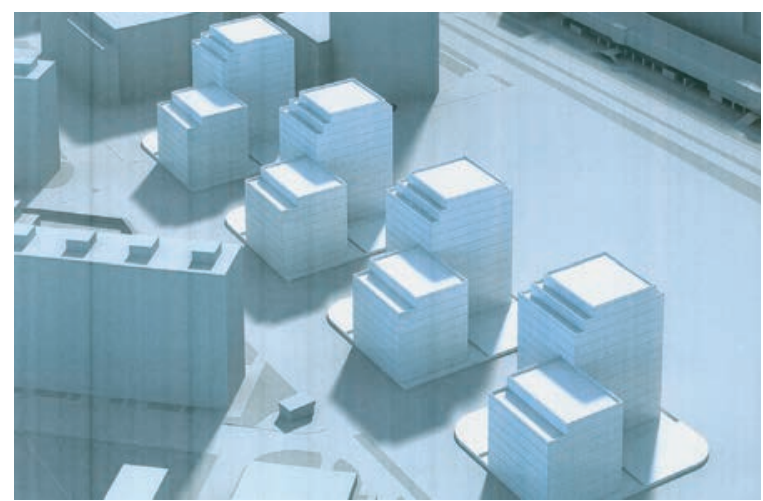

Ryc. 2. Ograniczenie możliwości zabudowy w związku z kształtem działki

Źródło: opracowanie własne
Innego rodzaju przykładem jest odstąpienie części własności nieruchomości kolejowej dla szeroko pojętego „dobra ogólnego", które interpretować można zarówno jako interes publiczny czyli poprawę dostępu publicznego do dworca kolejowego, jak również jako poprawę wizerunku otoczenia dworca centralnego w Warszawie oraz całego miasta. Rezygnacja z własności części gruntu kolejowego wiązała się z odstępstwem od ustawy o transporcie kolejowym oraz rozporządzenia wykonawczego w sprawie odległości zabudowy od obiektów kolejowych, co stanowi potencjalne zagrożenie bezpieczeństwa obiektów kolejowych i podróżnych (ryc. 3).

Interes społeczny jako klauzula generalna niedookreślona, obejmuje nie tylko oczywiste poprawy infrastrukturalne, lecz również wyższe potrzeby społeczne dotyczące kulturalnego i estetycznego otoczenia, zarówno najbliższego, jak też w skali miasta czy regionu. Stąd bierze się społeczna akceptacja nowoczesnej zabudowy, zamiany zdekapitalizowanych obiektów

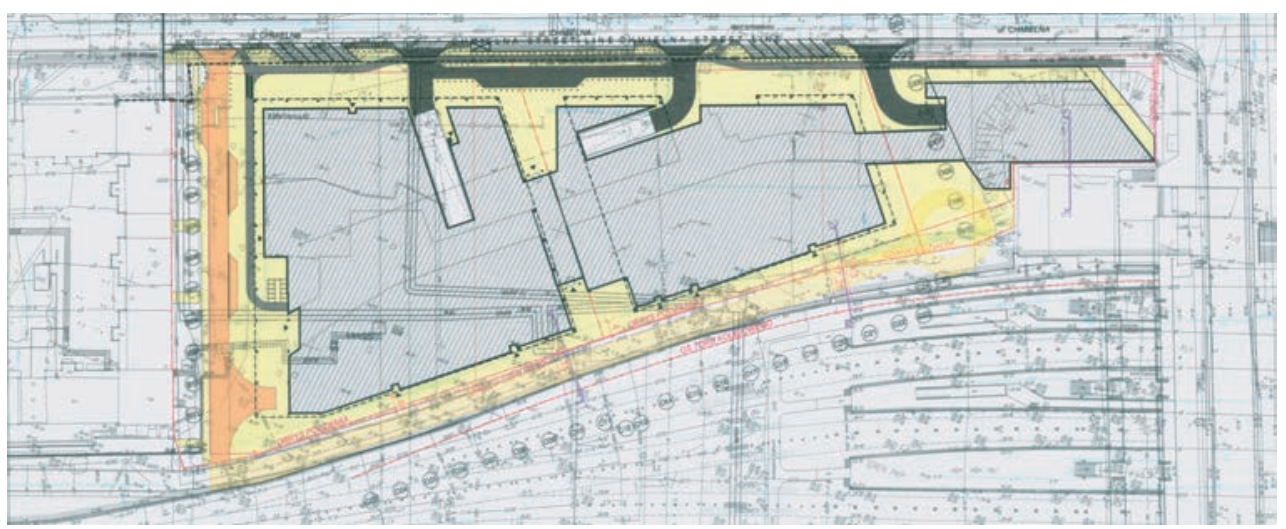

Ryc. 3. Zbliżenie zabudowy do terenów kolejowych służące poprawie wizerunku miasta Źródło: opracowanie własne 
na atrakcyjne wysokie budynki, stanowiące dominanty w określonych fragmentach miasta, ponadto przynoszące inwestorom zazwyczaj korzystne wyniki ekonomiczne.

Przykładem uzasadnionej ingerencji w prawa własności dla dobra ogólnego może być projekt dużego kompleksu handlowo-rozrywkowego, przygotowany na specjalnie wyznaczonej przez miasto działce, przedstawiony na rycinie 4 . Realizacja tej inwestycji uzasadnia pozbawienia prawa własności do dwóch małych, niewielkiej wartości budynków, z oczywistą rekompensatą finansową.

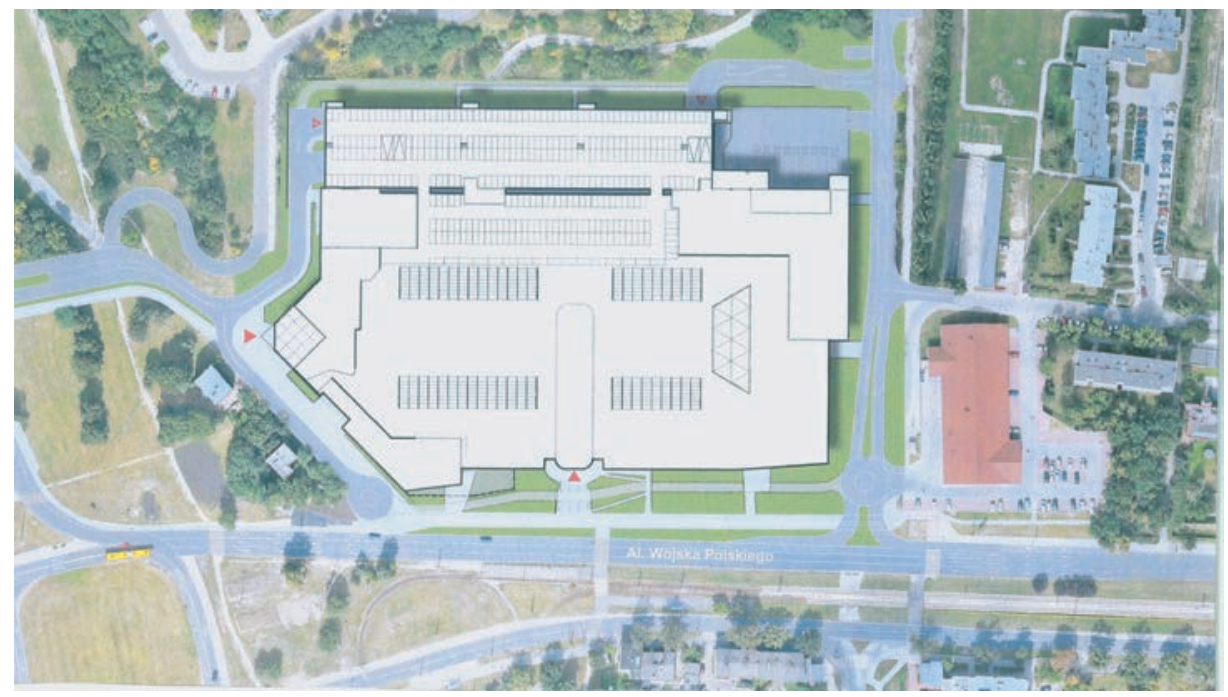

Ryc. 4. Uzasadniona likwidacja starej zabudowy

Źródło: opracowanie własne

Budownictwo, zwłaszcza wysokie, wywiera jednak istotny wpływ na znaczny obszar zabudowanej części miasta, sprowadzający się z reguły do naruszenia praw właścicielskich ustalonych w warunkach technicznych, a dotyczących zapewnienia określonego nasłonecznienia mieszkań i innych obiektów oraz zapewnienia niezbędnej odległości pomiędzy budynkami. Oznacza to, że przepisy techniczno-budowlane powinny uwzględniać nie tylko interesy inwestora, lecz również właścicieli nieruchomości znajdujących się w obszarze oddziaływania projektowanej inwestycji.

Przykładem może być wykres przedstawiający wpływ projektowanej budowy Mennica Tower na znaczny obszar miasta, przygotowany pod kątem sprawdzenia skali zacienianych mieszkań (ryc. 5). Obszar ten obejmuje aż 29 budynków z potencjalnie zacienianymi mieszkaniami poniżej wymaganego czasu nasłonecznienia. Konsekwencją szczegółowej analizy jest $\mathrm{w}$ takich przypadkach identyfikacja konkretnych mieszkań i stopnia wpływu projektowanego budynku na ich zacienianie, obliczone w czasie rzeczywistym. Wynikiem końcowym jest sformułowanie utraty wartości zacienionych mieszkań, a więc pozbawienie właścicieli części prawa własności, wymagające rekompensat wpływających na koszty planowanej inwestycji. 


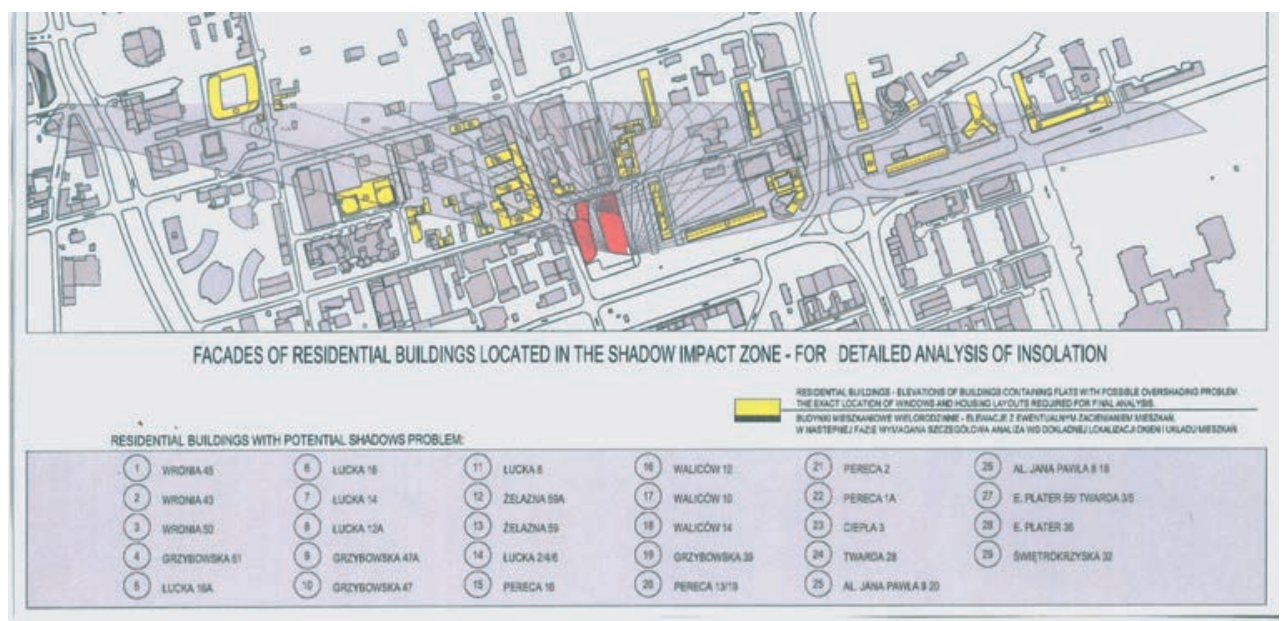

Ryc. 5. Zasięg wpływu wysokich budynków na otoczenie

Źródło: opracowanie własne

Przykład szczegółowej analizy zacieniania w konsekwencji wybudowania projektowanego wysokiego budynku przedstawia rycina 6 . W celu ograniczenia liczby potencjalnie zacienionych mieszkań projektant przewidział kilkukondygnacyjny prześwit, redukujący skutki zacieniania nawet z dość odległego, lecz wysokiego budynku (PKiN).

Społeczny interes rozwoju wysokiego budownictwa, zwłaszcza w gęstej miejskiej zabudowie, $\mathrm{z}$ jednej strony uzasadniany wizerunkiem miasta, lecz z drugiej strony ekonomiczną efektywnością wykorzystania cennych, uzbrojonych terenów, wymaga nadzoru administracyjnego, wspartego swego rodzaju kontrolą społeczną.

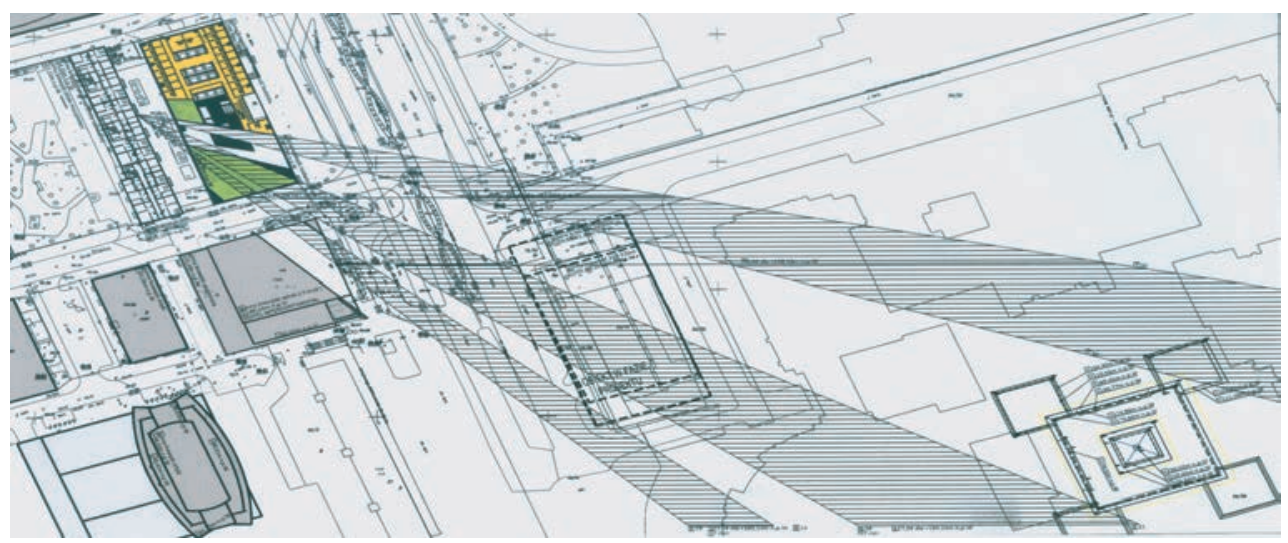

Ryc. 6. Indywidualny przykład ograniczania liczby mieszkań zacienianych Źródło: opracowanie własne 


\section{Kontrolna rola informacji publicznej}

Projekty architektoniczne budynków, zwłaszcza wysokich i o znacznych kubaturach, spełniać muszą szereg warunków określonych w ustawach i rozporządzeniach wykonawczych, często poddawane są uzgodnieniom z właściwymi specjalistycznymi organami oraz konsultacjom z rzeczoznawcami, by wreszcie uzyskać decyzję o pozwoleniu na budowę.

Według warunków Prawa budowlanego [Ustawa Prawo budowlane 1994] przed rozpoczęciem robót budowlanych, a praktycznie również przed uzyskaniem decyzji o warunkach zabudowy ( $w$ przypadku terenu nieobjętego miejscowym planem zagospodarowania przestrzennego), o projektowanym zamierzeniu inwestycyjnym powinny zostać poinformowane „strony”, a więc właściciele, użytkownicy wieczyści lub zarządcy nieruchomości znajdujących się w obszarze oddziaływania obiektu.

Konsekwencją zapisu art. 61. Konstytucji dotyczącego praw obywatelskich do dostępu do informacji publicznej, jest możliwość wglądu "stron” do projektowanych lub podjętych już decyzji związanych z zamierzeniami inwestycyjnymi. Jest to bardzo istotna społeczna rola kontrolna w odniesieniu do organów administracji gminnej - wydającej decyzje o warunkach zabudowy, jak też administracji państwowej (starostw) - wydających decyzje o pozwoleniu na budowę.

Przedmiotem tej swoistej kontroli społecznej jest zazwyczaj wgląd w projekty architektoniczno-budowlane składane do organu zatwierdzającego projekt i wydającego decyzjęo pozwoleniu na budowę, jak również koncepcje projektowei plany zagospodarowania terenów. W uzasadnionych przypadkach naruszenia warunków technicznych powodujących również naruszenie praw własnościowych, występuje potrzeba korekty projektu, bądź podjęcia postępowania zmierzającego do uzyskania zgody na odstępstwo i ustalenia rekompensaty za naruszenie prawa własności.

„Mimo ugruntowanego stanowiska sąów administracyjnych, zgodnie z którymi projekt architektoniczno-budowlany stanowi informację publiczna, w dalszym ciagu pojawiaja się watpliwości $w$ zakresie kwalifikowania projektu budowlanego jako informacji publicznej i udostepniania go na zasadach i w trybie ustawy o dostępie do informacji publicznej" [Smarż 2017, s. 3].

\section{Ekonomiczne konsekwencje egzekwowania prawa własności}

Przedstawiona w skrócie istota prawa własności, określona w podstawowych ustawach, powoduje wymierne korzyści, ale również konkretne koszty eksploatacji: porządkowe, podatkowe, opłat lokalnych, a także naruszeń prawa ochrony środowiska, na przykład przy usuwaniu drzew. Wartość nieruchomości gruntowych coraz częściej ocenia się bowiem nie na podstawie porównań z cenami transakcyjnymi podobnych terenów, lecz ich zdolnością do generowania zysków, uzyskiwanych zazwyczaj z eksploatacji możliwych do wybudowania na analizowanym terenie mieszkań, biur lub innej powierzchni usługowej. Stąd bierze się operowanie wartością gruntu wyrażaną w liczbie „pum” lub „pub”, stanowiącą podstawę kalkulacji. 
Kryterium kalkulacji staje się powierzchnia nieruchomości, stanowiąca formalnie czyjąś własność, lecz obarczona przepisami prawa (miejscowego planu zagospodarowania przestrzennego) lub decyzjami o warunkach zabudowy. Decydent określający wysokość dopuszczalnej zabudowy na określonej przestrzeni, jak również minimalny obszar biologicznie czynny - ogranicza prawa własności w imię interesu społecznego.

Podstawową rolą projektantów staje się wykorzystanie maksymalnych, dopuszczalnych warunków zabudowy, niestety często kosztem architektonicznych wizji nowej zabudowy. W szacowaniu wartości nieruchomości gruntowych podejście porównawcze, polegające na wyciąganiu wniosków z cen transakcyjnych okolicznych gruntów, staje się tylko elementem porównań, wymagającym konfrontacji z metodą inwestycyjną. W metodzie tej przeprowadza się rachunek „,chłonności” terenu pod budowę określonego rodzaju obiektów oraz zdolności uzyskanej powierzchni do prawdopodobnych zysków.

Występuje sytuacja konieczności uwzględniania wpływu obu tych metod na „końcową” wartość nieruchomości gruntowej. Egzekwowanie prawa własności na własnym terenie, po zamierzonej jego zabudowie, ograniczone jest nie tylko wspomnianymi już przepisami, lecz również kosztami spowodowanymi w wyniku naruszenia tych przepisów w stosunku do właścicieli zacienionych i przesłanianych mieszkań lub innych obiektów.

W przygotowywanym Kodeksie Urbanistyczno-Budowlanym 2017 (projekt $\mathrm{w}$ przygotowaniu) przyjęto zasadę, że „gospodarując przestrzenia, organy władzy publicznej kieruja się potrzeba zabezpieczenia interesu publicznego". W uzasadnieniu do projektu Kodeksu odniesiono się do kwestii własności, wyraźnie akcentując, że „Konstytucja formułuje zasadę zrównoważonego rozwoju już w art. 5 „znacznie wyżej w systematyce niż zasadę ochrony prawa własności"(Konstytucja RP art. 5).

Pryncypializm zasady dominującej roli interesu publicznego nad interesem prywatnym i skuteczne egzekwowanie tej zasady może prowadzić do przeciwdziałania szkodliwego rozpraszania zabudowy i suburbanizacji sprzecznej z ekonomiką inwestowania.

\section{Literatura}

Dyrektywa 2006/123/WE Parlamentu Europejskiego i Rady dotycząca usług na rynku wewnętrznym, Dz.U. UE z 27.12.2006 r.

Gurgul S., 2017, Ustanowienie służebności przesyłu a postępowanie wywłaszczeniowe, Nieruchomości, 1. s. 17

Kodeks Urbanistyczno-Budowlany. Projekt wg stanu z maja 2017 r.

Rozporzadzenie Ministra Infrastruktury z dnia 12 kwietnia 2002 r. ws sprawie warunków technicznych, jakim powinny odpowiadać budynki i ich usytuowanie, Dz.U. z 2015 r., poz. 1422.

Sąd Najwyższy: Wyrok z 2002 r. II CZ 138/01. LEX nr 54556. 


\section{Społeczna funkcja własności w planowaniu przestrzennym Witold Andrzej Werner}

Smarż J., 2017, Projekt architektoniczno-budowlany jako informacja publiczna w świetle aktualnego orzecznictwa, Budownictwo i Prawo, 1.

Trybunał Konstytucyjny: Wyrok z 2008 r., K 61/07, Dz.U. z 2008 r., nr 223, poz. 1475.

Ustawa z dnia 23 kwietnia 1964 r. Kodeks Cywilny, Dz.U. z 2016 r., poz. 394.

Ustawa z dnia 7 lipca 1994 r. Prawo budowlane, Dz.U. z 2016 r., poz. 290.

Ustawa z dnia 2 kwietnia 1997 r. Konstytucja Rzeczypospolitej Polskiej.

Ustawa z dnia 21 sierpnia 1997 r. o gospodarce nieruchomościami, Dz.U. z 2015 r., poz. 1774.

Ustawa z dnia 27 marca 2003 r. o planowaniu i zagospodarowaniu przestrzennym, Dz.U. z 2016 r., poz. 778 z późn. zm.

\section{The social function of property in spatial planning}

\section{ABSTRACT}

Socio-economic development increasingly calls for revised interpretations of the right of ownership that would impose restraints on the owners in exercising their right. Rather than being an absolute substantive right, the right of ownership is a social function; its boundaries are delimited by legislative acts as well as by the public interest and the standards of communal conduct. Ownership of real property plays a special role with respect to spatial planning, both at the macro level and at the level of individual investment projects, by virtue of being an immanent part of its economic consequences. Restraints on the right of ownership are applied by government agencies and municipal authorities, whose task is not only to issue legally sound compulsory purchase orders, but also to ensure that the compensations paid to owners are commensurate with their losses. In the process of ownership changes, an important controlling role is played by public information programs enabling any concerned owners to inspect the envisaged transformations.

Key words: essence of ownership, public interest

Prof. dr hab. inż. arch. Witold Andrzej Werner, rzeczoznawca budowlany w specjalności architektonicznej obejmujacej projektowanie recognised european valuer; doradca $i$ ekspert w procesach inwestycyjnych; honorowy członek Towarzystwa Naukowego Organizacji i Zarządzania; członek Sekcji Inżynierii Przedsięwzięć Budowlanych KILiW PAN, profesor zwyczajny w Wyższej Szkole Ekologii i Zarzadzania w Warszawie - Wydział Architektury, kontakt: witold.werner@wp.pl

Professor Witold Werner, Ph.D., Sc., Eng. University of Ecology and Management - Faculty of Architecture, contact:witold.werner@wp.pl 